\title{
Hydrogen Energy: a New Dimension for the Energy Cooperation in the Northeast Asian Region
}

\author{
Sergei Popov ${ }^{1, *}$, Darya Maksakova ${ }^{1}$, Oleg Baldynov ${ }^{1}$, Konstantin Korneev $^{2}$ \\ ${ }^{1}$ Department of Complex and Regional Problems in Energy, Melentiev Energy Systems Institute of Siberian Branch of the Russian \\ Academy of Sciences (ESI SB RAS), 664033, 130 Lermontov st. 130, Irkutsk, Russia \\ ${ }^{2}$ Center for Japanese studies, Institute of the Far East of the Russian Academy of Sciences (IFE RAS), 117997, 32 Nakhimovsky Av., \\ Moscow, Russia
}

\begin{abstract}
The Northeast Asian Region is a home for the major world's energy importers and Russia - the top energy exporter. Due to the depletion of national fossil energy resources, the industrialised East Asian economies are facing serious energy security issues. The snapshot of the intraregional energy trade in 2019 was analysed in terms of development potential. Japan, Korea and China are at the frontline of hydrogen energy technologies commercialisation and hydrogen energy infrastructure development. The drivers for such endeavours are listed and national institutions for hydrogen energy development are characterised. The priorities related to regional cooperation on hydrogen energy in Northeast Asia were derived on the basis of hydrogen production cost estimations. These priorities include steady development of international natural gas and power infrastructure. The shared process will lead to the synergy of regional fossil and renewable resources within combined power and hydrogen infrastructure.
\end{abstract}

\section{Introduction}

Hydrogen energy is one of the key components in the energy transition paradigm, which implies energy systems transformation. The hydrogen role in this process is to replace traditional internal combustion powertrains with fuel cells and provide opportunities for power grid regulation. The former means electrification of transportation, which will eventually complete a substitution of fossil energy for renewable energy in transportation vehicles. The latter allows daily and seasonal regulation of electric power systems on a large scale. Thus, the drivers to develop hydrogen energy in the Northeast Asian (NEA) region comprise the following:

- decreasing import dependency on fossil energy,

- preventing air pollutions and improving environmental quality,

- siting energy value chain in the domestic market,

- stimulating innovations,

- reshaping the structure of energy services costs,

- opening new opportunities to expand the countries' presence in the innovative global and regional markets,

- keeping up with the Paris agreement and global climate mitigation initiatives.

The implementation of the energy transition paradigm in the NEA economies will lead to the transformation of the traditional global energy markets and discoveries of new patterns of regional cooperation.

\footnotetext{
${ }^{a}$ The Harmonized System (HS) is international nomenclature defined by the World Customs Organisation (WCO) for the
}

The purpose of the study is to identify new opportunities that are opening up with the development of hydrogen energy in the NEA region. The objectives include analysing the current state of energy cooperation in the region, assessing the possibilities of hydrogen production technologies in the long term, and making the implications about hydrogen energy influence on regional energy cooperation.

\section{The current status of the energy cooperation within the NEA region}

The region is a net energy importer, with the combined share of China, Japan, R.Korea and Taiwan comprising almost half of the global energy import in energy terms. The resource factor in the NEA region provides favourable environment for the regional primary energy exporters to access the largest energy market. The geographical factor favours maritime trade, which is usually more competitive than the trade based on stationary infrastructure such as railways and pipelines. Major indicators of intraregional energy trade for the year 2019 are presented in Table 1, including total import and export volumes for coal, natural gas, crude oil, petroleum products, and electricity trade, as well as the respective shares for intraregional trade. Finally, energy carriers (HS $27)^{\mathrm{a}}$ trade values are indicated for all the seven regional economies.

classification of products, to establish common basis for custom purposes.

\footnotetext{
Corresponding author: popovsp@isem.irk.ru
} 
In 2019 total energy import to the NEA economies exceeded 370 bln international dollars, and intraregional energy turnover was estimated at 190 bln international dollars. Russia is a major regional energy donor with 66 bln dollar export to the East Asian economies, and export to import ratio exceeding 110 times. Mongolia is next with 2.5 times indicator, and lastly, R. Korea presents some 10 percent excess of regional energy export over regional energy import in monetary terms.

The Korean phenomenon arises from crude oil, coal and natural gas imports outside of the NEA region and petroleum products export to the neighbouring East Asian economies. China is adjacent to Russia in terms of mutual energy turnover within the NEA region (some $63 \mathrm{bln}$ ), followed by R.Korea (31 bln.), Japan (20 bln.), Taiwan (7 bln.), and Mongolia with the turnover of 4.5 bln international dollars.

The major intraregional energy flows are mutual deliveries of petroleum products (HS 2710, mostly petrochemicals).

China is highly dependent on intraregional energy bidirectional flows of electricity and coal (between 33 and 83 percent), and petroleum products import (41 percent).

Table 1. Major indicators of the Northeast Asia economies' energy trade in 2019.

\begin{tabular}{|c|c|c|c|c|c|c|c|}
\hline $\begin{array}{ll}\text { Indicators } & \text { Economies }\end{array}$ & Russia & China & Japan & R.Korea & Taiwan & DPRK & Mongolia \\
\hline \multicolumn{8}{|c|}{ Coal (HS 2701) } \\
\hline Total import (export), mln ton & $21(205)$ & $198(6)$ & $186(-)$ & $141(-)$ & $67(-)$ & $-(-)$ & $-(36)$ \\
\hline The share of NEA, percent & $-(39)$ & $33(83)$ & $12(-)$ & $22(-)$ & $14(-)$ & $-(-)$ & $-(99)$ \\
\hline \multicolumn{8}{|c|}{ Natural Gas (HS 271111 + HS 271121) } \\
\hline Total import (export), mln ton & .. (189) & $97(0.07)$ & $77(-)$ & $41(-)$ & $17(-)$ & $-(-)$ &..$(-)$ \\
\hline The NEA share, percent & $-(15)$ & $2.6(100)$ & $8(-)$ & $6(-)$ & $9(-)$ & $-(-)$ & $100(-)$ \\
\hline \multicolumn{8}{|c|}{ Crude Oil (HS 2709) } \\
\hline Total import (export), mln ton & .. (269) & $239(0.8)$ & $147(-)$ & $143.1(-)$ & $44(-)$ & $-(-)$ & -0.8 \\
\hline The NEA share, percent & $-(34)$ & $15(38)$ & $5(-)$ & $6(-)$ & $-(-)$ & $-(-)$ & $-(-)$ \\
\hline \multicolumn{8}{|c|}{ Petroleum Products (HS 2710) } \\
\hline Total import (export), mln ton & $0.6(143)$ & $30.6(55)$ & $23(19)$ & $32(65.8)$ & $13(22)$ & $0.0(0.0)$ & $1.8(-)$ \\
\hline The NEA share, percent & $17(15)$ & $41(9)$ & $36(32)$ & $24(38)$ & $26(6)$ & $100(-)$ & $100(-)$ \\
\hline \multicolumn{8}{|c|}{ Electricity (HS 2716) } \\
\hline Total import (export), TWh & $1.6(3.5)$ & $5.3(1.4)$ & $-(-)$ & $-(-)$ & $-(-)$ & $0.03(0.3)$ & $1.7(0.03)$ \\
\hline The NEA share, percent & $2(17)$ & $72(33)$ & $-(-)$ & $-(-)$ & $-(-)$ & $100(100)$ & $100(100)$ \\
\hline \multicolumn{8}{|c|}{ Energy (HS 27) } \\
\hline Total import (export), bln int. dol & $1.9(221)$ & $344(37)$ & $156(14)$ & $127(42)$ & $44(13)$ & $0.06(.)$. & $1.3(3.2)$ \\
\hline The NEA share, percent & $30(30)$ & $17(11)$ & $10(35)$ & $12(38)$ & $11(14)$ & $100(100)$ & $100(100)$ \\
\hline
\end{tabular}

0.0 - less then 100000 ton;

..- less then 10000 ton

Source: author's estimations based on castom statistics from trademap.org

Mongolia and DPRK have critical dependence on regional energy supply, particularly, on electricity import swallowed by China. The DPRK's energy export and import are extremely low due to the sanctions of the UN 
Security Council, so the regional energy cooperation is under the great stress for this economy.

Russia seems to be significantly involved in the NEA regional energy market. The share of East Asian economies reached 30 percent both in total Russia's energy export and import in 2019. In the same year the share of Northeast Asia in total Russia's export accounted for 39 percent for coal, 34 percent for oil, 17 percent for electricity, and 15 percent both for natural gas and petroleum products.

For Japan, R.Korea and Taiwan, regional energy cooperation is important in terms of petroleum, coal and natural gas imports. Regional import of crude oil for Japan and R.Korea are marginal between 5-6 percent, while it is equal to zero for Taiwan.

Recent transformations of the national gas and electricity market institutions in Japan and China, coupled with the regional and global natural gas market developments, give some hope to expect more active regional cooperation on natural gas and electricity. Considering the perspectives for natural gas demand growth in China and the resource potential in Russia, the development of gas infrastructure will be one of the most perspective objectives for energy cooperation in the NEA region in the coming decades.

\section{The Hydrogen National Institutions in the NEA region}

Hydrogen technologies development is one of the most important issues within the energy transition framework, when energy strategy is considered in the energy-deficient industrial economies of East Asia. This section presents a short scope of the national-scale hydrogen institutions in the each NEA economy.

\subsection{The case of China}

The energy development strategy action plan for the period 2014-2020 adopted by the State Council in 2014 [1] highlights the transition to low carbon energy as one of the key strategic guiding principles. The document prioritises the increasing role of natural gas, renewable energy (wind, solar and geothermal) and nuclear energy. Besides, the document includes hydrogen energy and fuel cell (FC) in the 20 key technologies to be developed.

The issue of a national hydrogen strategy was raised at the third session of the 13th National People's Congress in May 2020 [2]. However, several provinces and cities have already issued hydrogen energy development plans.

In 2018 China Hydrogen Alliance was established by state-owned China Energy Investment Corporation and the other 17 sponsors. The aim is to enhance the development of China's hydrogen sector by providing policy advice and serving as a platform to coordinate efforts for the development and commercialisation of hydrogen technologies. The alliance is supported and supervised by the Ministry of Science and Technology and other government bodies [3].

According to the White paper [4] prepared by the Alliance, hydrogen consumption in China will have risen up to 35 million tons or 5 percent of the final energy demand by 2030. By 2050 the figures should achieve 60 million tons and 10 percent, correspondingly. The number of fuel cell vehicles (FCV) will have grown to 50 thousand by $2025,1.3$ million by 2035 and 5 million by 2050 .

It is worth noting that the White paper sets ambitious targets for renewable energy. The share of water electrolysis using renewables in hydrogen supply should achieve 15 percent by 2030,45 percent by 2040 and 70 percent by 2050, in comparison with 3 percent in 2020 .

\subsection{The case of Japan}

Japan is at the third wave of hydrogen technologies development now. The first one was in the early 1990s, the second one followed in a decade, and the third wave started around 2015.

In 2014 the Ministry of Economy, Trade and Industry provided a new Basic Plan for sustainable energy transition under the " $3 \mathrm{E}+\mathrm{S}$ " motto. It is interpreted as Energy security, Environment (emissions reduction), Economic affordability (competitive cost) and [inherited] Safety. Hydrogen's contribution to the Basic Plan looked undoubted because of four effects: decarbonisation, mitigation of the dependence on particular fossil fuel exporters, ability to utilize low cost feedstock and new opportunities for innovative developments. As a further step, the Basic Hydrogen Strategy (world's first national strategy of such a type) was adopted in 2017. The idea was to make Japan a "hydrogen nation" with a wide range of new industries, including transportation and digital devices, which use hydrogen for power generation [5].

In May 2018 the Non-fossil Fuel Energy Value Trading Market was established at the Japan Electric Power Exchange. This is a green certificates market where non-fossil fuel energy power producers sell "nonfossil fuel energy certificates", which evidence to energy retailers that electricity is green, i.e. it was originated exclusively from renewable primary energy. The certificates can be traded separately from actual electricity [6].

Japan aims to use green hydrogen in power generation and other industries in the future. At present, the government is examining the replacement of existing fuels and raw materials with green hydrogen and the associated costs for various industrial processes. The combination with carbon capture, utilisation and sequestration (CCUS) is necessary in order to produce blue hydrogen from natural gas or coal.

Considering insufficiency of the domestic renewable energy resources, Japan looks for hydrogen supply chains from overseas, in addition to Australia and Brunei, where demonstration experiments are ongoing.

\subsection{The case of R.Korea}

In January 2019 the R.Korea adopted a Hydrogen Roadmap [7]. The major goal is to shift the demand from transport sector from oil-based fuels to electricity, including FCV. It is projected to consume more than 5.2 
million tons of hydrogen to power up to 6 million FCVs, $2 \mathrm{GW}$ of decentralised and $15 \mathrm{GW}$ of grid-operated FC generators by 2040 [8].

In addition to the Hydrogen Roadmap, some basic laws related to hydrogen economy and energy were drafted:

- The Hydrogen Act (will come into force on February $\left.5^{\text {th }}, 2021\right)$. It is expected that the Hydrogen Act will become the central legislation regulating the hydrogen industry, while the Renewable Energy Act will be used where an issue is not covered;

- The Hydrogen Economy Promotion and Hydrogen Safety Management Law (came into force in 2020). It consider the measures to create favourable environment for a hydrogen economy: the adoption of hydrogen programs by regional governments; support and subsidies for hydrogen companies engaged in the development of hydrogen technologies; the creation of the Hydrogen Economy Committee to facilitate the cooperation among the government, industry, academic, and civil experts on national and international stages [9].

The Ministry of Energy is primarily responsible for regulating the hydrogen industry. The promotion of the hydrogen industry will be carried out by the Hydrogen Convergence Alliance, a private organisation that aims to improve the competitiveness of hydrogen specialised companies.

The Korea Gas Corporation, a state enterprise, will establish a system for the distribution and transaction of hydrogen, and manage pricing for hydrogen. The Korea Gas Safety Corporation, a state enterprise, will oversee safety management, inspect safety standards for hydrogen related components and facilities, and support education, advertisement and international cooperation relating to hydrogen safety.

To provide green hydrogen, domestic and imported renewables are considered. The import of hydrogen related components will be regulated by the Hydrogen Act, which states that such components can be inspected by the Ministry of Energy or the local authority of the relevant city or district. The government will establish the Foreign Marketing Support Centre to assist with the export of hydrogen specialized companies [10].

Korean companies by their own initiatives participate in international organisations for hydrogen technologies development, like Hydrogen council, Fuel cell and hydrogen energy association, International association for hydrogen energy, etc.

\subsection{The cases of Taiwan, Mongolia and DPRK}

The policy towards hydrogen energy it this economies is still sporadic and non-systemic, and there are no special institutions established for hydrogen technologies and infrastructure development.

\subsection{The case of Russia}

The Energy Strategy of the Russian Federation up to 2035 was approved in June 2020 [11] Hydrogen technologies are considered as important means for energy storage and niche applications, mainly for transportation and autonomous energy supply. Importantly, hydrogen technologies for energy storage and conversion should be implemented to increase efficiency of power grid operations.

Export targets for hydrogen were set as a major indicator of the progress in hydrogen energy developments. In 2024 Russia is expected to export 0.2 million tonnes of hydrogen, and 2 million tonnes in 2035. However, the primary technologies for hydrogen export are supposed to be electrolysis powered by nuclear energy, or natural gas pyrolysis.

A Working Group on the development of hydrogen energy was established under the Ministry of Energy in November 2019. It includes Gazprom, Sberbank, Rosatom, academic and expert community representatives. The objectives of the $\mathrm{WG}$ are to develop support measures, review pilot projects, remove regulatory barriers, and create a road map for hydrogen technology development [12]

\subsection{The Section's Summary}

The lessons learned from the studies of the hydrogen national institutions in the NEA economies suggest that fuel switching from fossil to renewable energy for transportation, industrial and building energy services is considered as an important pattern for the long-term energy transition strategy.

Hydrogen technologies are pivotal for renewable energy based on the so-called "New Green Deal", designed to repower economies and reindustrialise global transportation sectors on innovative technological basis. Additionally, hydrogen energy is supposed to contribute significantly to securing energy supply and energy efficiency.

However, in order to build up hydrogen infrastructure at the first stage of the hydrogen energy development, hydrogen production from fossil energy (natural gas, coal, and petroleum products) will have a priority.

\section{Cooperation patterns: resources, infrastructure and hydrogen value chain}

When moving towards hydrogen energy, the cooperation patterns reflect the structure of hydrogen value chain. The chain links are hydrogen production, storage, transportation and distribution. Hydrogen production costs vary with energy sources and production methods, while hydrogen storage, transportation and distribution do not depend on primary energy sources.

Steam methane reforming, coal gasification and water electrolysis are the most widespread among the various hydrogen production methods. In steam methane reforming, natural gas (or another source of methane) reacts with steam to produce hydrogen and carbon dioxide. In coal gasification, coal is converted into a synthesis gas that is then transformed into hydrogen and carbon dioxide. Carbon capture, utilisation and storage can be applied to the both processes. Water electrolysis is an electrochemical process that splits water into hydrogen 
and oxygen. The process requires water as well as electricity [13].

IEA's estimations suggest that hydrogen production by water electrolysis using renewable energy can be competitive with hydrogen production from fossil fuels, including carbon capture and storage costs, in the long term (figure 1).

The main drivers are a significant drop in capital expenditures in water electrolysis in 2050 by a factor of 3.2 and a decrease in renewable electricity prices from USD 36-116 per MWh to USD 20-60 per MWh.

According to IEA's data [14], if blue and green hydrogen production are considered and resource prices and efficiency assumptions are not taken into account, then steam methane reforming is the cheapest process followed by water electrolysis and coal gasification. In the long term, water electrolysis can become more costeffective solution, competitive to steam methane reforming and coal gasification with CCUS. However, it is worth noting that a large reduction in capital expenses in water electrolysis is necessary to achieve such a competitiveness level.

Besides, the location of water resources and renewable energy potential should be considered when planning international power interconnections. Water scarcity in the arid areas with high wind and solar energy potential in Mongolia and China can be an important driver to create power interconnections in the NEA region allowing producing hydrogen in the eastern regions of Russia with sufficient water resources.

Thereby, efficient gas and electricity trade is the main prerequisite for hydrogen production in the NEA region in the middle and long term. This means that international gas and electricity infrastructure and favourable institutional frameworks are required to support gas and electricity trade and overall Energy Transition process in the region.

\section{Implications}

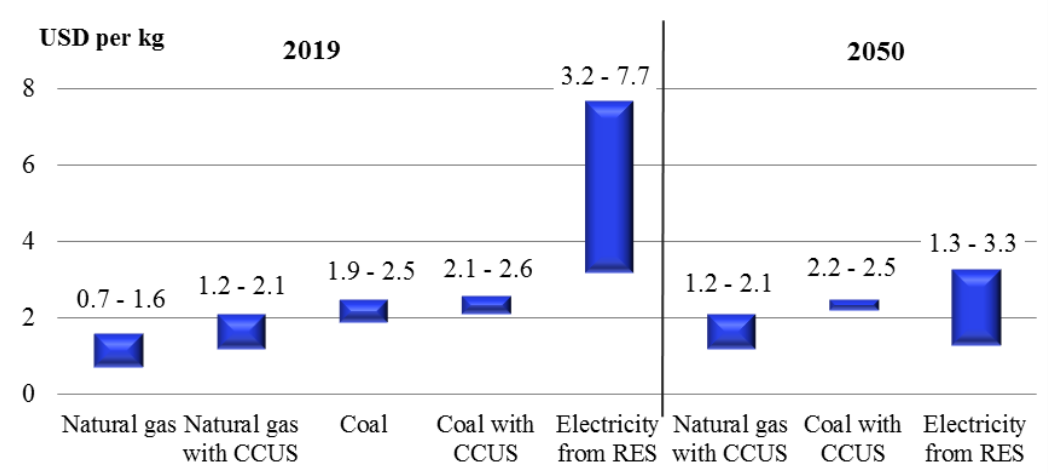

Fig.1. Hydrogen production costs.

Source: $\lceil 14\rceil$

The study was supported by RFBR research projects 18-51094006 and 20-014-00024.

\section{References}

1. Energy development strategy action plan (20142020) (State Council of the People's Republic of Northeast Asia.
The Energy Transition process in the highly energy import dependent East Asian countries is led by hydrogen technologies. Hydrogen energy is considered as a major tool for dealing with complex issues focused on energy supply chains in industrialised, export-oriented, and environmentally-concerned economies. Remastering energy services for transportation sector through electrification, partly based on fuel cells technologies, will have numerous consequences in terms of energy security, environmental quality improvements, innovative developments, and new value chains creation.

In addition to their inherited low-carbon feature, hydrogen technologies are important for power grid regulation and decentralisation of building's energy services.

The national hydrogen strategies in the major East Asian economies are focused more on hydrogen consumption and transportation than hydrogen production. However, hydrogen itself is just an energy carrier, not a primary energy resource. We are entering on a long transition period, when hydrogen production derived from fossil fuels will be more economically feasible than green hydrogen (based on renewable energy).

Considering the stabilisation of primary energy demand in coming decades, descending demand for coal and oil, remaining superior efficiency for hydrogen production from natural gas, we expect the growth in natural gas regional trade and cooperation in natural gas infrastructure development.

Additionally, with the rapidly declining costs of renewable energy, green hydrogen production and seasonal hydrogen storage will end up in fusion of power grid and hydrogen energy infrastructure on regional scale.

Such electro-hydrogen infrastructure will be an ultimate energy system with 100 percent renewable primary energy supply. The task for energy researchers is to demonstrate the feasibility of such a system in 
China,

Availible: http://www.gov.cn/xinwen/202005/30/content 5516227.htm (accessed: 20.09.2020).

3. About China $\bar{H}$ ydrogen Allience (China Hydrogen Alliance, 2020) Availible:

http://www.h2cn.org/en/about.html\#survey (accessed: 20.09.2020).

4. White Paper on China Hydrogen and Fuel Cell Industry (China Hydrogen Alliance, Beijing, 2019) Availible:

http://www.h2cn.org/Uploads/File/2019/07/25/u5d3 96adeac15e.pdf (accessed: 20.09.2020).

5. Basic Hydrogen Strategy (Ministry of Economy, Trade and Industry, 2017) Availible: https://www.meti.go.jp/english/press/2017/pdf/1226 _003a.pdf (accessed: 20.09.2020).

6. M. Niunoya, M. Shima, K. Masaki, Hydrogen in Japan (CMS, 2020) Availible: https:/cms.law/en/int/expert-guides/cms-expertguide-to-hydrogen/japan (accessed: 20.09.2020).

7. The government announces Hydrogen Economy Roadmap (Ministry of Trade, Industry and Energy, 2019) Available: https://www.motie.go.kr/common/download.do?fid $=$ bbs\&bbs_cd_n $=81 \& b b s \_s e q \_n=161262 \&$ file_seq $\mathrm{n}=2$ (accessed: 20.09.2020).

8. Hydrogen Economy Development in Korea (Netherlands Enterprise Agency, The Hague, 2020) Availible:

https://www.rvo.nl/sites/default/files/2020/07/Korea -Hydrogen-economy-overview-2020-final.pdf (accessed: 20.09.2020).

9. Korea launches hydrogen economy drive to foster hydrogen-related businesses (Ministry of Trade, Industry and Energy, 2020) Available: https://english.motie.go.kr/en/tp/energy/bbs/bbsVie w.do?bbs_seq_n=978\&bbs_cd_n=1\&view_type_v= 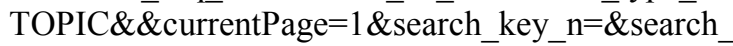 val_v=\&cate_n=3 (accessed: 20.09 .2020$)$.

10. Z. Song, Hydrogen in South Korea (CMS, 2020) Available: https://cms.law/en/int/expert-guides/cmsexpert-guide-to-hydrogen/south-korea (accessed: 20.09.2020).

11. Energy Strategy of the Russian Federation up to 2035 (the Government of the Russian Federation, Moscow, 2020) Available: http://static.government.ru/media/files/w4sigFOiDj GVDYT4IgsApssm6mZRb7wx.pdf (accessed: 20.09.2020).

12. Pavel Sorokin has held a meeting with the working group on hydrogen energy development in the Russia Federation (The Ministry of Energy of the Russian Federation, 2020) Available: https://minenergo.gov.ru/node/16922 (accessed: 20.09.2020).

13. IEA, The Future of Hydrogen: Seizing Today's Opportunities (International Energy Agency, Paris, 2019) Available: https://www.iea.org/reports/thefuture-of-hydrogen (accessed: 20.09.2020).
14. IEA, Global average levelised cost of hydrogen production by energy source and technology, 2019 and 2050 (IEA, Paris, 2020) Available: https://www.iea.org/data-andstatistics/charts/global-average-levelised-cost-ofhydrogen-production-by-energy-source-andtechnology-2019-and-2050 (accessed: 20.09.2020). 